\title{
ON THE ORIGIN OF THE SHIELD BOSSES OF THE TYPE DOBRODZIEŃ
}

\author{
M I C H E L K A Z A N S K I ${ }^{(0)}$
}

\begin{abstract}
The shield bosses of the type Dobrodzień possess typical longitudinal flutes or facets on the calotte. These artefacts are well known in the Barbaricum, particularly in the Middle Danube area and to the north of the Carpathians, with a few isolated finds documented to the east of the Carpathians, on the eastern Black Sea coast, and on the Roman empire's Danubian frontier. The images of the shield bosses of the type Dobrodzien rarely occur on the Roman pictures (the Monza diptych) and on the metalware discovered in the Barbaricum (horse tack plates from Untersiebenbrunn). The period of existence of the shield bosses of the type Dobrodzień as a whole corresponds to 370s-430s. The article suggests the Roman origin of this weaponry: most likely, it was manufactured in a workshop in the Middle Danube area. Moreover, it is still possible that there were some Germanic prototypes for faceted shield bosses were known in the Germanic context already in the late $1^{\text {st }}$ and $2^{\text {nd }} \mathrm{c}$.
\end{abstract}

Keywords: Middle Danube area, Great Migration Period, shield boss, Stilicho.

The shield bosses called Dobrodzień-Zieling T type (Kazanski 1988, 76, fig. 6; 7; 2019; Ščukin 1992; Zieling 1989, 160-162) stand out for their spheroconical, rather high calotte featuring vertical fluting or faceting and sometimes a horizontal flute at the base of the calotte and relatively narrow eaves. This article will discuss the possible origin of these artefacts. Most finds of these shield bosses originate from barbarian sites in Central Europe relatable with the Germans from the Late Roman and Early Migration periods (Fig. 1: a). Therefore, the artefacts in question are sometimes called Germanic (see e.g. Feugère 1993, 248). However, there is one shield boss discovered in the Eastern Baltic context, in a grave at the cemetery of Krikštonys in the Neman area (Appendix no. 1; Fig. 2: 1). In the European Barbaricum east of the Carpathians, there is only one known shield boss discovered at the settlement from the Roman period called Zaliski, in Western Ukraine (Appendix no. 10; Fig. 2: 3). There are three shield bosses originating from the territory of present-day Abkhazia on the eastern Black Sea coast (Appendix no. 11; 12; Fig. 3: 6-8). Finally, there is a shield boss found in the territory of the Roman Empire, in the fort of Hinova on the Danube (Appendix no. 13; Fig. 3: 5).

Discussing the shield bosses of the type Dobrodzien, it is worth mentioning their ancient images. The best known is a diptych from Monza (Fig. 4: 1), which is most often related to the famous Roman military commander of Vandal origin Stilicho and is dated to ca 395 (for details see: Kiilerich/Torp 1989, with bibliography). I would like to call the researchers' attention to the distinct image of a shield boss of the type Dobrodzien on circular horse tack plates from the all-known grave in Untersiebenbrunn in Lower Austria (Fig. 4: 2; see e.g. Tejral 2011, fig. 125). It is demonstrative that the fine 'shield boss' from Untersiebenbrunn shows the same star-shaped field as that of the shield boss from the Monza diptych. The find from Untersiebenbrunn is a reference point for the Stage D2 (the so-called Untersiebenbrunn horizon) of the Barbaricum timeline (380s/400s-440s/450s). According to the summary of the finds in close assemblages, the shield bosses of the type Dobrodzien possibly date from the late Stage C3 (generally, 300s/320s-350s/370s) to the early Stage D2 (380s/400s-440s/450s) according to the European Barbaricum timeline, i.e. 370s-430s (for details see: Kazanski 2019, 160-163, with bibliography).

Although almost all the known shield bosses in question originate from the barbarian, primarily Germanic, context, I think it sounder that this weaponry type was of the Roman origin: perhaps it was initially related to the workshops in Pannonia and Noricum. An argument supporting the Roman origin of these shield bosses is the already mentioned diptych from Monza (Fig. 4: 1). I think it would be totally improbable to imagine Stilicho, similarly to any other highranked barbarian living in the Empire as a possible 


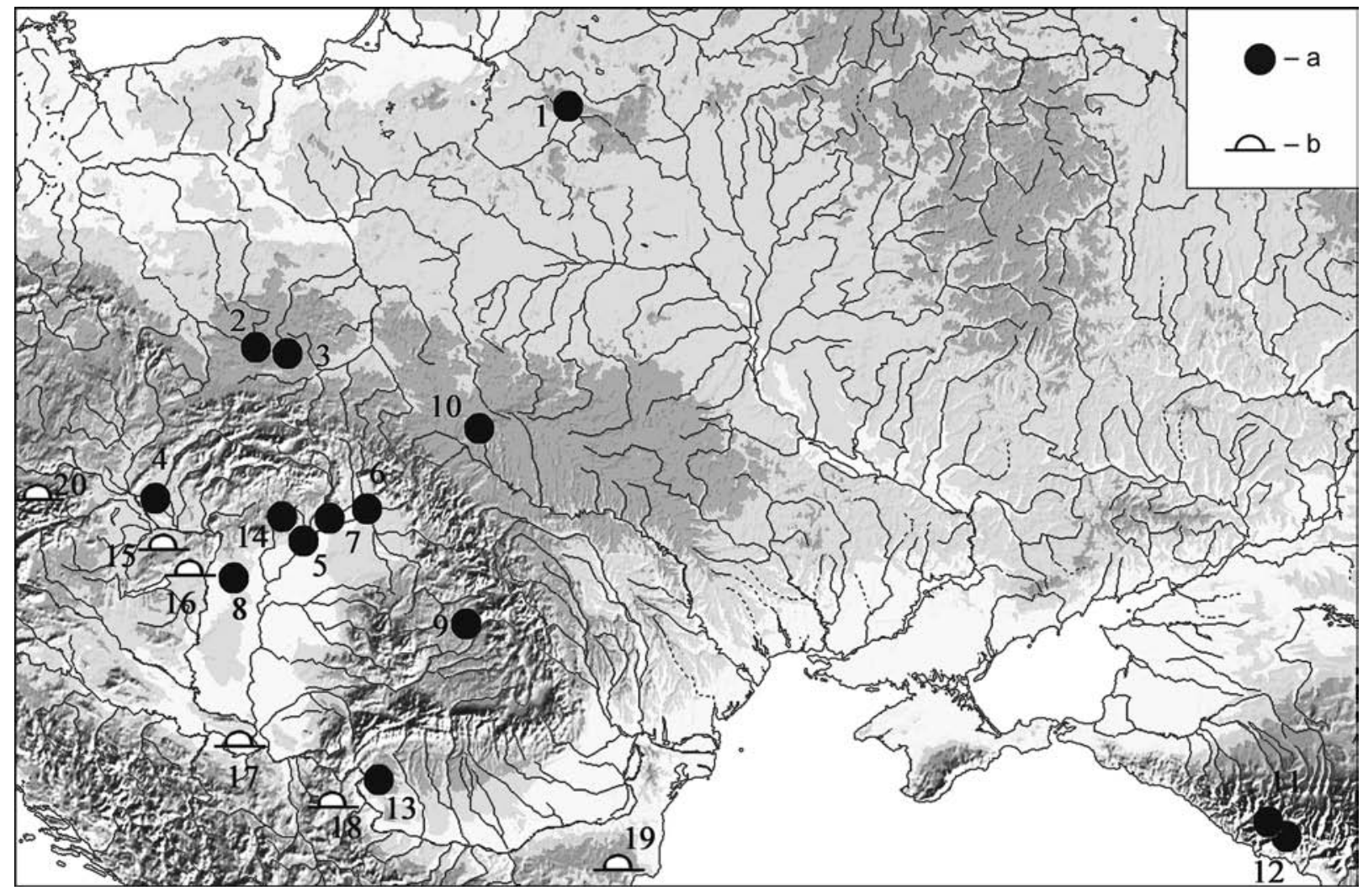

Fig. 1. Distribution map. a - the shield bosses of the type Dobrodzien (after Kazanski 2019, fig. 1); b - the location of the scutaria on the Danube (after Bishop/Coulston 1993, fig. 135). 1 - Krikštonys (App. no. 1); 2 - Dobrodzień (App. no. 2); 3 - Olsztyn (App. no. 3); 4 - Mušov (App. no. 4); 5 - Tiszavalk (App. no. 5); 6 - Tiszakarád-Inasa (App. no. 6); 7 - TiszadobSziged (App. no. 7); 8 - Ujhartyán (App. no. 8); 9-Budeşti (App. no. 9); 10 -Zaliski (App. no. 10); 11 -Shapka-Abgydzrakhu (App. no. 11); 12: Shapka-Akh'iatsrarkhu (App. no. 12); 13 - Hinova (App. no. 13); 14 - Szihalom-Budaszög (App. no. 14); 15 - Carnuntum; 16 - Aquincum; 17 - Sirmium; 18 - Horreum Margi; 19 - Marcianopolis; 20 - Lauriacum.

owner of the diptych, agreeing to have any 'barbarian' feature on his official portrait. Such an interpretation contradicts all what we already know about the integration of barbarians into the Roman governmental structure. 'Barbarian' material culture was absolutely not acceptable to the Western Roman power elite.

In 417 , a special decree prohibiting barbarian haircuts and barbarian clothes of animal hides/furs in Rome and neighbouring regions was published (Codex Theodosianus 14. 10. 4 as cited in: Chastagnol 1976, 94); according Pseudo-Aurelius Victor's account, Emperor Gratian (375-383) aroused the hatred of his troops against himself when he made public appearances wearing Alanic, i.e. barbarian, attire (Pseudo-Aurelius Victor, Epit., 411. 47: Gratian and Maximus). It hardly was any general of barbarian origin in Roman service allowing himself such an extravagant behaviour. It is worth remembering that Stilicho was actually accused of having barbarian sympathies (Stein 1959, 253; Rutilus Namatianus, De reditu 2. 16-60, as cited in:
Chastagnol 1976, 83, 84), which finally appeared the cause of his murder.

There is an interpretation of the 'barbarian' shield boss on the Monza diptych as an evidence of the new fashion launched by the leaders of barbarian foederati (Kargopol'tsev/Bazhan 1993, 117). This fashion really existed in the Great Migration: in the Western Roman Empire, it is documented by military leaders' graves of the Untersiebenbrunn horizon (see above), such as Mundolsheim, Fürst, Lébény-Magasmart, and Lengyeltóti (for details see Kazanski 1999). However, the commanders of the troops of barbarian foederati in Roman service represented by these graves were obviously ranked lower than Stilicho or Roman generals in general. Along with their barbarians, they actually were outside the Roman society, so they did not order official diptychs for themselves. As for the case of Stilicho, he had no relation to the leaders of foederati, being the commander of the Western Roman Empire's regular army (Stein 1959, 226). It should be noted that the shield boss's typical star-shaped 


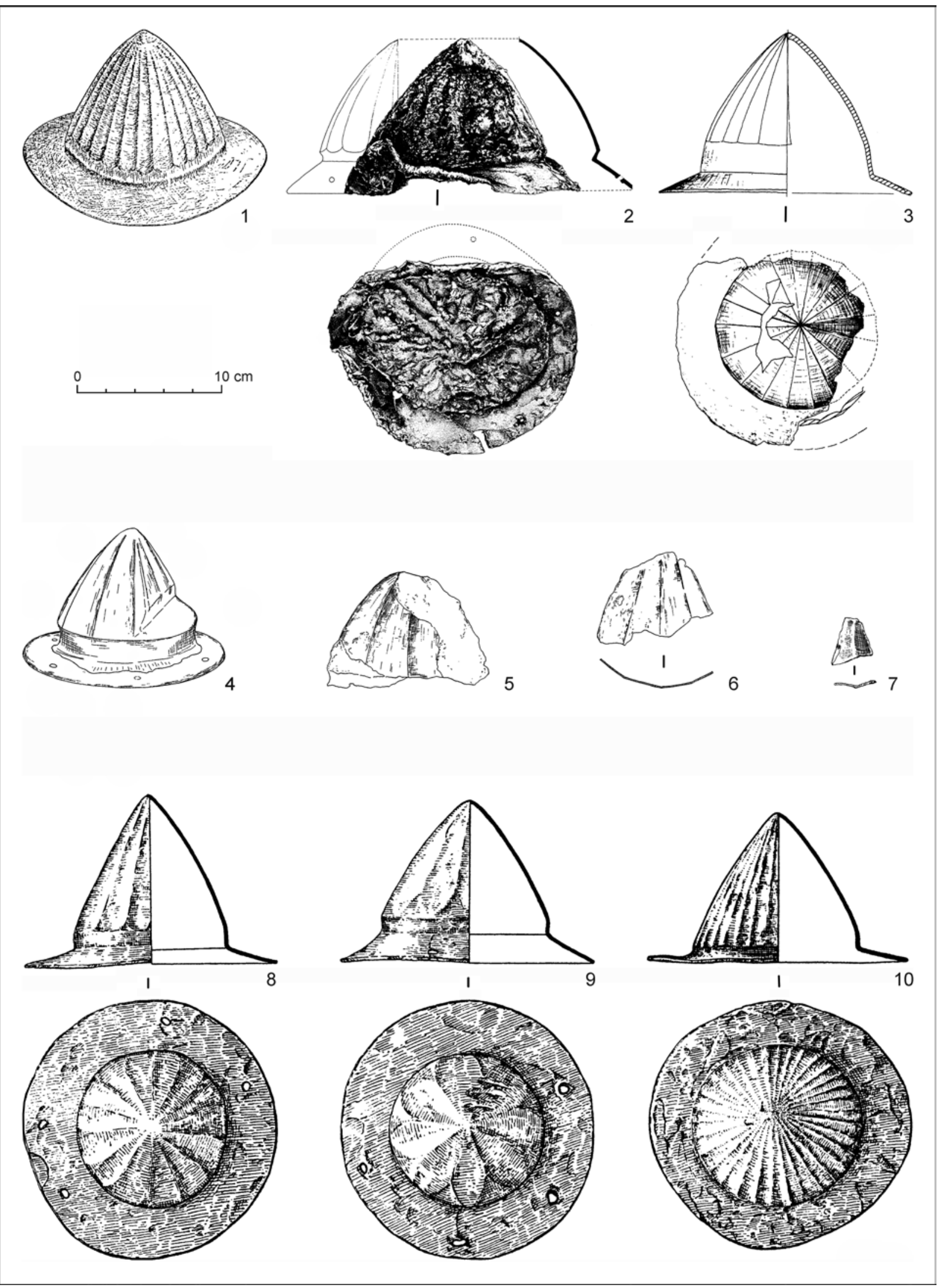

Fig. 2. Shield bosses of the type Dobrodzień. 1 - Krikštonys, grave 2; 2 - Tiszadob-Sziged, grave 34; 3 - Zaliski; 4-6 - Dobrodzień; 7 - Olsztyn; 8-10 - Mušov, building 10 (after Kazanski 2019, fig. 2; 3). 

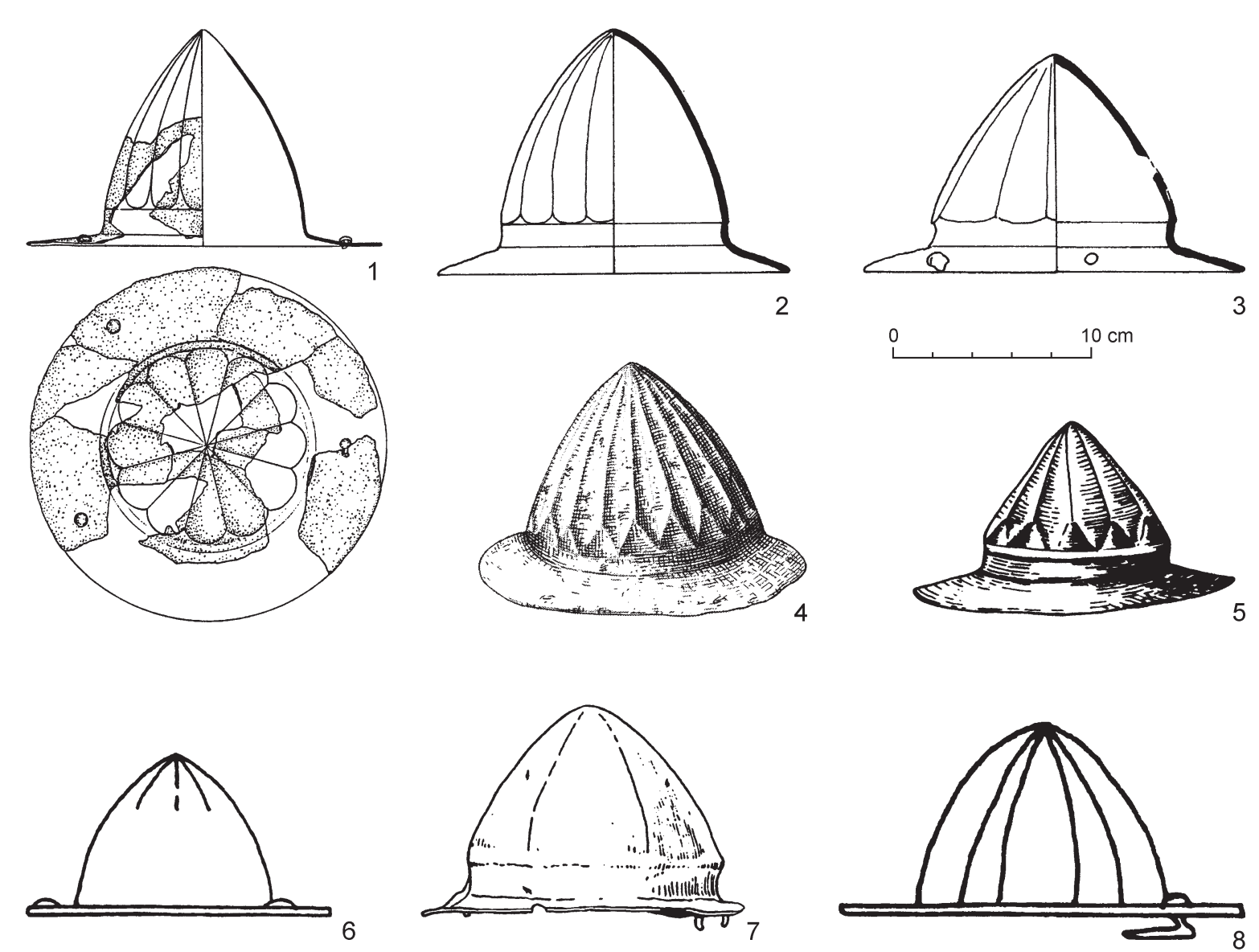

Fig. 3. Shield bosses of the type Dobrodzień (continueation). 1 - Tiszavalk, grave 6; 2 - Tiszakarád-Inasa; 3 - Budeşti; 4 - Ujhartyán; 5 - Hinova; 6 - Shapka-Abgydzrakhu, out of context; 7 - Shapka-Abgydzrakhu, grave 6; 8 - ShapkaAkh'iatsrarkhu, grave 20 (1-4, 6-8 - after Kazanski 2019, fig. 4-6; 7 - after Harhoiu 1998, 177, pl. LXXXIII: E).

eaves depicted on the diptych from Monza and on the horse tack from Untersiebenbrunn meet with parallels among reliably attributed Roman shield bosses from the first half of the $3^{\text {rd }} \mathrm{c}$. discovered in the fort of Dura Europos on the Euphrates (Fig. 5; James 2004, 175, fig. 95, no. 603, 604; see also Przybyła $2014,217)$ and are not known on the shield bosses from the Barbaricum.

According to their geographic location in the epicentre of the shield bosses of the type Dobrodzien distribution area (Fig. 1: a), the Empire's provinces on the Danube, primarily Pannonia and Noricum, gave the best fit for the production area of these shield bosses, and more precisely, their prototypes. Let me remind that according to the Noticia Dignitatum, these Danubian provinces of the Empire, and particularly Lauriacum, Carnuntum, Aquincum, and Sirmium, housed the most part of the state workshops, scutaria, which made shields for the Roman army (Fig. 1: b). Moreover, there are more elements of the material culture in the Barbaricum which obviously spread from the Roman provinces on the Danube, such as the artefacts showing stamped designs (for details see: Kazanski/Mastykova 2017, with bibliography). Another argument for the Roman rather than barbarian attribution of the shield bosses of the type Dobrodzien is their appearance in the eastern coast of the Black Sea (Fig. 1: 11, 12). Although there were German elements dated from the Great Migration period in this region, first, their number there was much smaller than it is commonly considered, and second, these German elements penetrated to the eastern Black Sea coast with the Roman army (for details see: Kazanski 2015).

However, there still is a certain 'barbariantrack'. Actually, the shield bosses with faceted calotte, possibly distant predecessors of the shield bosses of the type Dobrodzień, are known in the Barbaricum as early as the Roman period. 


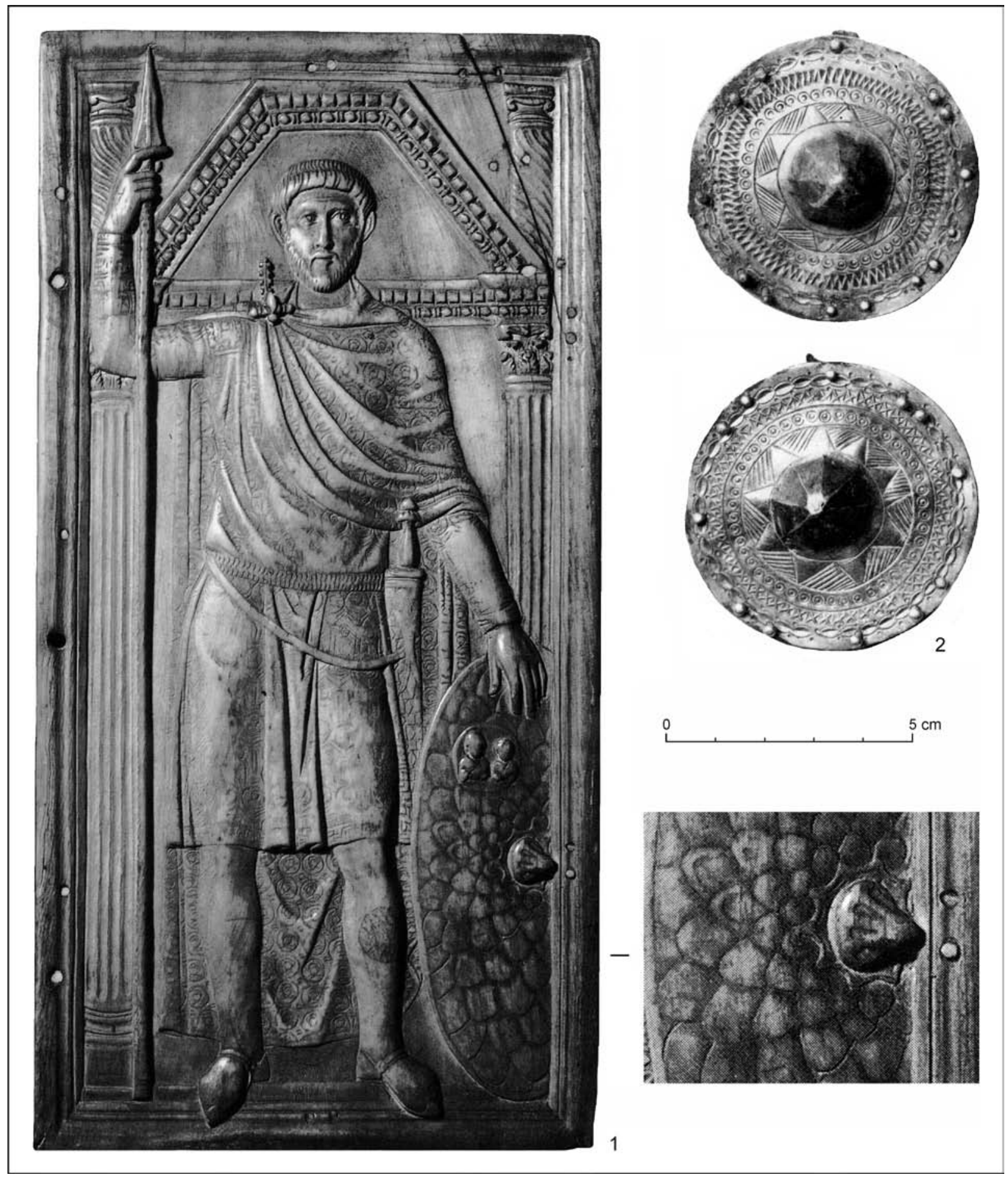

Fig. 4. The images on: 1 - the diptych from Monza; 2 - a horse tack from Untersibenbrunn (after Kazanski 2019, fig. 7).

It is the case of the shield boss with a pin, of the type Zieling B2d, from grave 2 of the cemetery of Drogichin-Kozarovka (Polish Drohiczyn-Kozarówka) in western Belorussia which belonged to the Przework culture (Fig. 6: 8; Szmit 1921, fig. 39: 47; Zieling 1989, 731, 732, No. 1029; fig. 8). The shield boss with a pin, of the type Zieling B2d, and also the brooch of the type Almgren 111 from the same grave (Fig. 6: 6) belonged to Stage B2 of the 'barbarian' timeline, i.e. $70 \mathrm{~s} / 80 \mathrm{~s}-160 \mathrm{~s} / 170$ s. It is still possible that further studies would gradually fill in the gap in between of the faceted shield bosses from the Roman period and those of the type Dobrodzień. 


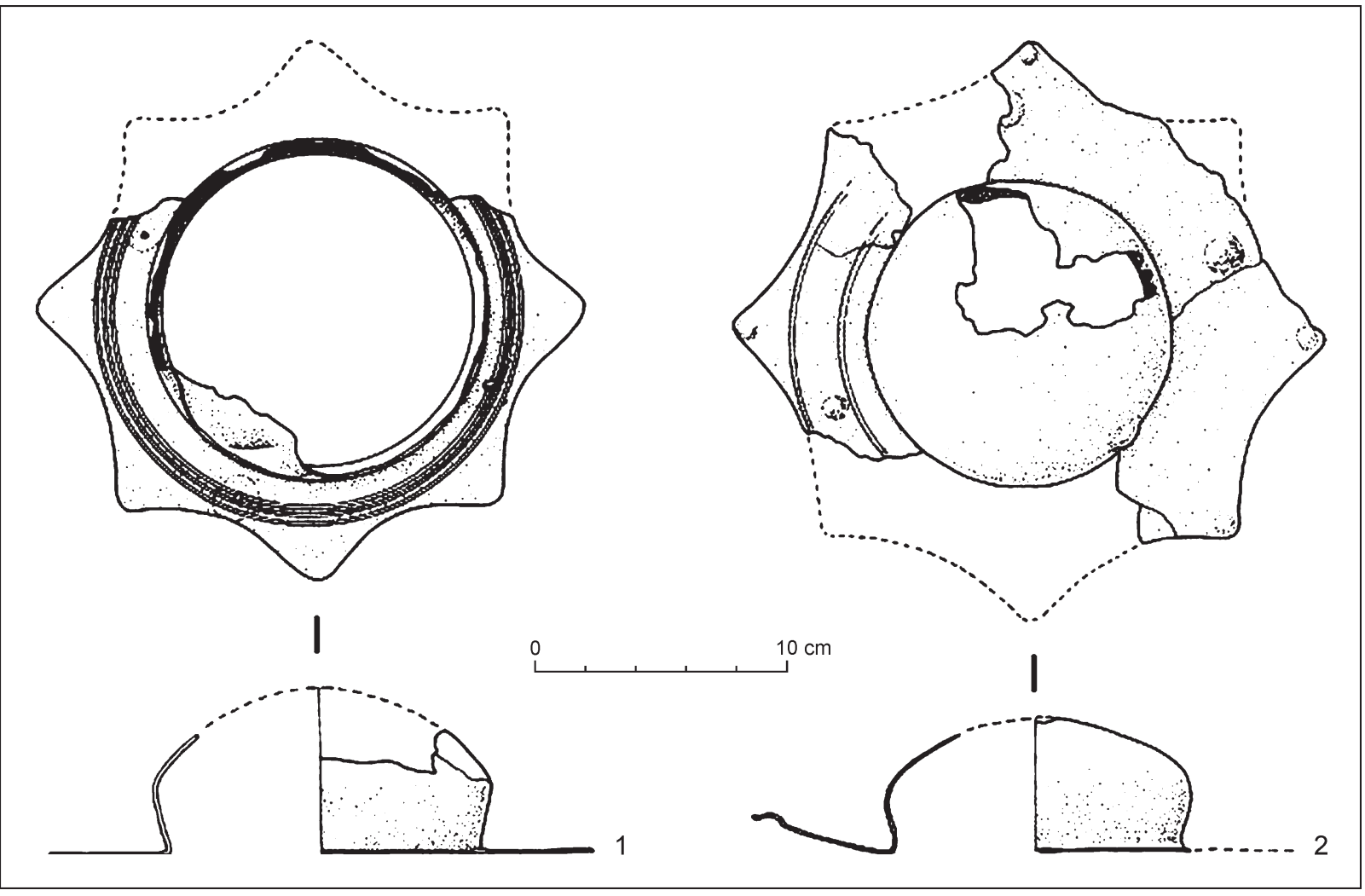

Fig. 5. A Roman shield boss from Dura Europos (after James 2004, fig. 95; no. 603, 604).

\section{APPENDIX}

\section{The finds of the Shield Bosses of the Type Dobrodzień}

1. Krikštonys (Lazdiju distr.), grave 2 (Fig. 1: 1; 2: 1). Kulikauskas 1959, fig. 9; Kazakevičius 1988, 126, 128; Zieling 1989, no. 1961

2. Dobrodzień-Rędzina (Opole voi.), cemetery, cremation graves layer (Fig. 1: 2; 2: 4-6). Szydłowski 1974, 77, pl. XCIII; XCV; Zieling 1989, no. 996-1001.

3. Olsztyn (Warmian-Masurian voi.), cemetery, cremation graves layer (Fig. 1: 3; 2: 7). Szydłowski 1974, 141, pl. CLXVII: e, f; Zieling 1989, no. 1319, 1320.

4. Mušov (Břeclav distr.), building 10 (Fig. 1: 4; 2: 8-10). Trňáčková 1985; Tejral 1986, fig. 15: 1, 2; 2011, 207, fig. 79: 1, 3,4 .

5. Tiszavalk (Borsod-Abaúj-Zemplén county), grave 6 (Fig. 1: 5; 3: 1). Garam/Vaday 1990, fig. 10, 11; Istvánovits/Kulcsár 1987-1989, 63, pl. II: 3.

6. Tiszakarád-Inasa (Borsod-Abaúj-Zemplén county), grave 35 (Fig. 1: 6; 3: 2). Istvánovits/Kulcsár 1987-1989, 63, pl. II: 1 .

7. Tiszadob-Sziged (Szabolcs-Szatmár-Bereg county), grave 34 (Fig. 1: 7; 2: 2). Istvánovits/Kulcsár 1987-1989, 63, fig. 14: 2, 15; pl. II: 4; Istvánovits 1993, fig. 14-16.
8. Ujhartyán (Pest county), an inhumation grave accompanied with a horse burial (Fig. 1: 8; 3: 4). Bóna 1961; Zieling 1989, no. 2006; Istvánovits/Kulcsár 1987-1989, 67, pl. II: 5; Tejral 2011, fig. 37.

9. Budeşti (Maramureş county), grave? (Fig. 1: 9; 3:3). Horedt 1982, 147-150; fig. 59: 2; Istvánovits/Kulcsár 1987-1989, 48, pl. II: 6 .

10.Zaliski (Shumsk distr.), a building (Fig. 1: 10; 2: 3). Kokowski 1996, fig. 1.

11. Shapka-Abgydzrakhu (Guilripsh distr.), grave 6 (Fig. 1: 11;3: 7), and a find out of the context (Fig. 3: 6). Trapsh 1971, 25-28, pl. III; XXXVI: 8; Kazanski 1994, 447, Appendix 2: 21: a, j; fig. 4: 3 .

12.Shapka-Akh'iatsrarkhu (Guilripsh distr.), grave 20 (Fig. 1: 12;3: 8). Trapsh 1975, 26, 27, pl. XVI: 5 (cited as an analogous artefact); XIX: 1 (cited as an analogous artefact); XXI: 3 (incorrect picture, for the image see: Voronov/ Shenkao 1982, fig. 5: 11); XXII: 3; XXIII: 5; XXIV: 2 (cited as an analogous artefact), 12; Kazanski 1994, 447, Appendix 2: 23; fig. 4: 1.

13. Hinova (Mehedinți county), the Late Roman fort (Fig. 1: 13; 3: 5). Davidescu 1980, 68, fig. 19: g; Harhoiu 1998, 177, pl. LXXXIII: E.

14. Szihalom-Budaszög (Heves county), grave X. 1. B (Fig. 1: 14). Fodor 1997, 123. 


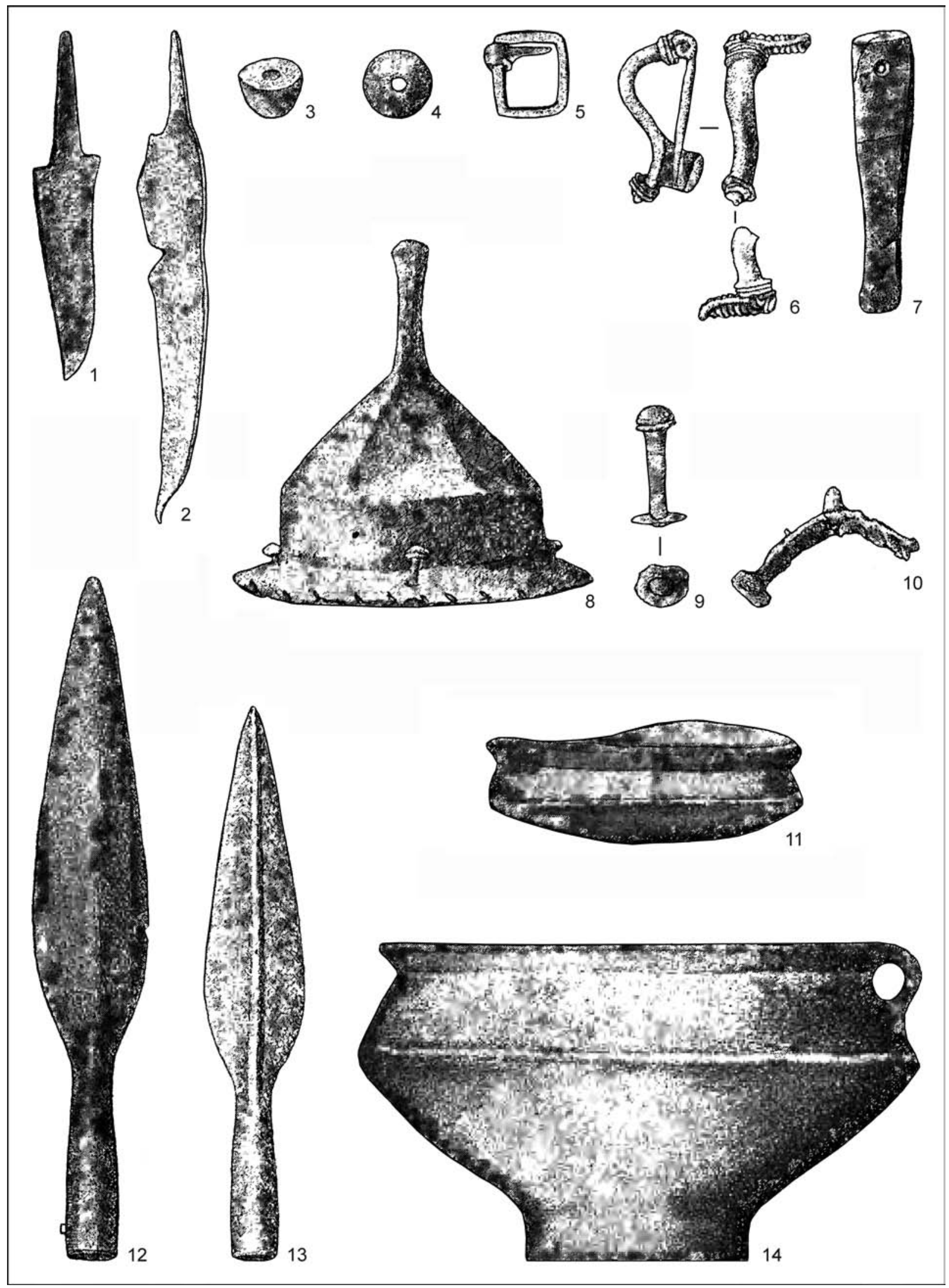

Fig. 6. Grave goods from grave 2 in the cemetery of Drogichin-Kozarovka (after Szmit 1921, fig. 39: B). 


\section{BIBLIOGRAPHY}

Bishop/Coulston 1993 - M. C. Bishop/J. C. N. Coulston: Roman Military Equipment from the Punic Wars to the fall of Rome. London 1993.

Bóna 1961 - I. Bóna: Az újhartyáni germán lovassír. Archeologiai Értesitó 88, 1961, 192-209.

Chastagnol 1976 - A. Chastagnol: La fin du monde antique. De Stilicon à Justinien (5 siècle et début 6). Paris 1976.

Davidescu 1980 - M. Davidescu: Cetatea romană de la Hinova. Bucureşti 1980.

Feugère 1993 - M. Feugère: Les armes des romaines de la République à l'Antiquité tardive. Paris 1993.

Fodor 1997 - L. Fodor: Szihalom-Budaszög. Késő szarmatak-kora népvándorlás kori temető a IV-V. századból - Szihalom-Budaszög. Late Sarmatian and Early Migration Period Cemetery from the A.D. $4^{\text {th }}-5^{\text {th }}$ Century. In: P. Raczky/T. Kovács/A. Anders (szrek. - eds.): Utak a múltba. Az M3-as autopálya régészeti leletmentései - Paths into the past. Rescue excavations on the M3 motorway. Budapest 1997, 120-123.

Garam/Vaday 1990 - É. Garam/A. H. Vaday: Sarmatische Siedlung und Begräbnisstätte in Tiszavalk. Communicationes Archaeologicae Hungariae, 1990, 171-219.

Harhoiu 1998 - R. Harhoiu: Die frühe Völkerwanderungszeit in Rumänien. Archaeologia Romanica 1. Bukarest 1998.

Horedt 1982 - K. Horedt: Siebenburgen in spätrömischer Zeit. Bukarest 1982

Istvánovits 1993 - E. Istvánovits: Das Gräberfeld aus dem 4.-5. Jahrhundert von Tiszadob-Sziget. Acta Archaeologica Academiae Scientiarum Hungaricae 45, 1993, 91-146.

Istvánovits/Kulcsár 1987-1989 - E. Istvánovits/V. Kulcsár: Pajzsos temetkezések a Dunától keletre eső kárpátmedencei Barbaricumban. A nyíregyházi Jósa András Múzeum Évkönyve 30-32, 1987-1989, 47-96.

James 2004 - S. James: The Excavations at Dura-Europos Conducted by Yale University and the French Academy of Inscriptions and Lettres, 1928 to 1937: Final Report VII, the Arms and Armour and Other Military Equipment. London 2004.

Kargopoltsev/Bazhan 1993 - S. Yu. Kargopoltsev/I. A. Bazhan: Umbony shchitov i boevye topory rimskogo vremeni. Peterburgskii arkheologicheskii vestnik 2, 1993, 113-126.

Kazakevičius 1988 - V. Kazakevičius: Oruzhie baltskikh plemen II-VIII vekov na territorii Litvy. Vilnius 1988.

Kazanski 1988 - M. Kazanski: Quelques parallèles entre l'armement en Occident et à Byzance ( $\mathrm{IV}^{\mathrm{e}}-\mathrm{VII}^{\mathrm{e}} \mathrm{s}$.). In: C. Landes (éd.): Gaule mérovingienne et monde méditerranéen. Les derniers Romains en Septimanie, IVe-VIII siècles. Actes des IX Journées d'archéologie mérovingienne, Lattes, 24-27 septembre 1987. Journées d'Archéologie Mérovingienne 9. Lattes 1988, 75-87.

Kazanski 1994 - M. Kazanski: Les éperons, les umbo, les manipules de boucliers et les haches de l'époque romaine tardive dans la région pontique: origine et diffusion. In: C. von Carnap-Bornheim (Hrsg.): Beiträge zu römischer und barbarischer Bewaffnung in den ersten vier nachchristlichen Jahrhunderten. Akten des 2. Internationalen Kolloquiums in Marburg a. d. Lahn, 20.-24. Februar 1994. Veröffentlichung des Vorgeschichtlichen
Seminars der Philipps-Universität Marburg 8. Lubin Marburg 1994, 429-485.

Kazanski 1999 - M. Kazanski: Les tombes des chefs militaires de l'époque hunnique. In: Th. Fischer/ G. Precht/J. Tejral (Hrsg.): Germanen beiderseits des spätantiken Limes. Materialien des 10. Internationalen Symposiums "Grundprobleme der frühgeschichtlichen Entwicklung im nördlichen Mitteldonaugebiet". Xanten vom 2.-6. Dezember 1997. Spisy Archeologického ústavu AV ČR Brno 14. Köln - Brno 1999, 293-316.

Kazanski 2015 - M. Kazanski: Germanskie elementy v material'noi kul'ture Abkhazii v pozdnerimskoe vremia i v epokhu pereseleniia narodov. Scripta antiqua. Voprosy drevnei istorii, filologii, iskusstva i material'noi kul'tury 4, 2015, 33-60.

Kazanski 2019 - M. Kazanski: Umbony tipa Dobrodzień epokhi pereseleniia narodov: rasprostranenie, proiskhozhdenie i datirovka. Stratum plus 4, 2019, 155-167.

Kazanski/Mastykova 2017 - M. Kazanski/A. Mastykova: The Sösdala Findings in the Perspective of Central and South-Eastern Europe. In: C. Fabech/U. Näsman (eds.): The Sösdala Horsemen and the Equestrian Elite of Fifth Century Europe. Jutland Archaeological Society publications 99. Højbjerg 2017, 297-311.

Kiilerich/Torp 1989 - B. Kiilerich/H. Torp: Hic est, hic Stilicho. The Date and Interpretation of a Notable Diptych. Jahrbuch des Deutschen Archäologischen Instituts 104, 1989, 319-371.

Kokowski 1996 - A. Kokowski: W kwestii rozprzestrzeniania się umb z facetowaną pokrywą (typ Dobrodzień). In: A. Kośko (red.): Z badań nad geneza regionalizmu kulturowego społeczeństw Kujaw. Studia i materiały do dziejów Kujaw - Niżu Polski 6. Poznań 1996, 179-187.

Kulikauskas 1959 - P. Kulikauskas: Naujas archeologinis paminklas Użnemunèje (V-VII amžių jotvingių senkapis Krikštonyse, Lazdijų raj). Lietuvos TSR Mokslu akademijos darbai. Serija A 1(6), 1959, 71-88.

Przybyła 2014 -M. J. Przybyła: Foederati na Zelandii? Analiza uzbrojenia pochówku z pierwszej poł. III w. po Chr. z Aasø, Zelandia. In: R. Madyda-Legutko/ J. Rodzińska-Nowak (red.): Honoratissimum assensus genus est armis laudare. Studia dedykowane Profesorowi Piotrowi Kaczanowskiemu z okazji siedemdziesiatej rocznicy urodzin. Kraków 2014, 213-224.

Pseudo-Aurelius Victor, Epit. - C. L. F. Panckoucke (ed.)/ N. A. Dubois (tr.): Pseudo-Aurelius Victor. Épitomé de Caesaribus. Online available at: https://fr.wikisource. org/wiki/Epitomé_de_Caesaribus

Ščukin 1992 - M. B. Ščukin: A propos des contacts militaires entre les Sarmates et les Germains à l'époque romaine (d'après l'armement et spécialement les umbo des boucliers et les lances). In: F. Vallet/M. Kazanski (éd.): L'armée romaine et les Barbares du III a au VIIe siècle. Actes du colloque international, Saint-Germain-en-Laye 24-28 février 1990. Memoires de l'Association française d'archéologie mérovingienne 5. Rouen 1992, 323-334. Stein 1959 - E. Stein: Histoire du Bas-Empire. Tome premier. De l'Etat Romain à l'Etat Byzantin (284-476). Paris 1959. 
Szmit 1921 - Z. Szmit: Groby z okresu lateńskiego i rzymskiego na cm. «Kozarówka» w Drohiczynie nad Bugiem. Wiadomości Archeologiczne 6, 1921, 61-70.

Szydłowski 1974 - J. Szydłowski: Trzy cmentarzyska typu dobrodzieńskiego. Rocznik Muzeum Górnośląskiego w Bytomiu. Archeologia 11. Bytom 1974.

Tejral 1986 - J. Tejral: Fremde Einflüsse und kulturelle Veränderungen nördlich der mittlerer Donau zu Beginn der Völkerwanderungszeit. In: J. Kmieciński (red.): Peregrinatio Gothica. Archaeologia Baltica 7. Łódź 1986, 175-238.

Tejral 2011 - J. Tejral: Einhemische und Fremde. Das norddanubische Gebiet zur Zeit der Völkerwanderung. Spisy Archeologického ústavu AV ČR Brno 33. Brno 2011.

Trapsh 1971 - M. M. Trapsh: Trudy v chetyrech tomach. Tom 3. Kul'tura tsebel'dinskikh nekropolei. Tbilisi 1971.

Manuscript accepted 7. 6. 2021

Translated by Nikita Khrapuno
Trapsh 1975 - M. M. Trapsh: Kul'tura gornoi Abkhazii v nachale epokhi srednevekov'ia. In: M. M. Trapsh: Trudy $v$ chetyrech tomach. Tom 4. Materialy po arkheologii srednevekovoi Abkhazii. Sukhumi 1975, 9-87.

Trǔáčková 1985 - Z. Trňáčková: Ein Hortfund von metallgegenständen aus der späten Kaiserzeit und frühen Völkerwanderungszeit aus Mušov. Památky archeologické 86, 1985, 279-284.

Voronov/Shenkao 1982 - Yu. N. Voronov/N. K. Shenkao: Vooruzhenie voinov Abkhazii IV-VII v. In: A. K. Ambroz/I. F. Erdeli (red.): Drevnosti epokhi velikogo pereseleniia narodov V-VIII vekov. Sovetsko-vengerskii sbornik. Moskva 1982, 121-165.

Zieling 1989 - N. Zieling: Studien zu germanischen Schilden der Spätlatène- und der römischen Kaiserzeit im freien Germanien. British Archaeological Reports International Series 505. Oxford 1989.

Michel Kazanski, dr. hab.

Centre national de recherche scientifique

UMR 8167 - Orient et Mediteranée

52, rue du Cardinal Lemoine

FR - 75231 Paris cedex 05

michel.kazanski53@gmail.com 
